\title{
EFFECT OF NITROGEN FERTILIZATION AND FOLIAR APPLICATION OF BORON ON FRUIT SET, VEGETATIVE GROWTH AND YIELD OF ANNA APPLE CULTIVAR ( Malus domestica Borkh ).
}

Nabil M.A.A. Al-Imam

Dept. of Horticulture and Landscape Design

College of Agriculture and Forestry

University of Mosul- IRAQ
Abd-Alrahman M.A. Al-Brifkany

Dept. of Horticulture

College of Agriculture

University of Duhok- IRAQ

\begin{abstract}
This Study was conducted at private apple orchard located at AL-Rashidia region in Mosul, Iraq, during the season of 2008 . To study the effect of different levels of Nitrogen fertilization $\left(0,60,120\right.$ and $180 \mathrm{KgN}^{-1} \mathrm{~h}^{-1}$ and foliar application of Boron $\left(0,50,100\right.$ and $\left.150 \mathrm{mgB} .1^{-1}\right)$ as boric acid $\mathrm{H}_{3} \mathrm{BO}_{3}(17 \% \mathrm{~B})$ on fruit set , vegetative growth and some quality and quantity of yield characteristics of Anna apple cultivar. The results showed response of apple trees to nutrient treatments especially with using $120 \mathrm{KgN} \cdot \mathrm{h}^{-1}$ which caused increased on fruit set, leaf area, total chlorophyll in the leaves, TSS in fruit, fruit weight and tree yield, while this treatment caused a significant decrease in total acidity in fruit. In the same direction of results when foliar application with $100 \mathrm{mgB} .1^{-1}$ for these characteristics. The best results of growth and quntity Anna, apple yield and quality were obtained by interaction between application containing $120 \mathrm{KgN} \cdot \mathrm{h}^{-1}+100 \mathrm{mg}$ B. $\mathrm{L}^{-1}$.
\end{abstract}

\section{INTRODUCTION}

Apple (Malus domestica L.) is a member of family Rosaceae and distributed worldwide. Anna is the one of apple cultivars accepted to be suitable and the lowchilling requirement (Krisanapook et al., 1995). In Iraq, many cultivars of apple are grown in different regions according to the diversity of their climatic necessity particularly average temperature and the requirement of chilling hours in the regions are available. Most pome fruit orchards need some fertilizers to achieve and maintain optimum tree growth and fruit production. Modern pome fruit production calls for greater attention to plant nutrition because of higher density planting, the need for higher fruit production from young plantings, replanting of old orchards due to a shortage of good new land increased demand for better quality fruit and never-longer storage times (Bright, 2005). Nitrogen is a major element, required by all plants, adequate nitrogen is essential for tree growth, leaf cover, blossom formation, fruit set and fruit size, all of which combine to determine crop yield (Mengel et al, 2001 and Bright, 2005). The efficient use of nitrogen fertilizers to increase crop yield is an important goal in all agricultural system (Dong et al.,2005). Nitrogen is required for the initial growth of deciduous trees in the spring during cell division (Ernani and Dias, 1999 and BI et al, 2003). Initial growth of fruit trees in spring is supported by remobilization of $\mathrm{N}$ reserves and there is a positive relationship between spring growth and the amount of $\mathrm{N}$ reserves for many species and varieties (Dong et al., 2005). Many workers have shown that fertilization fruit trees with nitrogen fertilizer have been increasing fruit set, vegetative growth and yield (Klein et al., 2006) on Starking Delicious apple trees;

Received 3/8/2010 accepted 21/10/2010 
Dong et al., 2005 on Fuji apple trees and Swierczynski et al., 2007 on two cultivars Idared and Jonagold of apple trees). Boron is an important micronutrient for trees. There is long list of roles of boron including sugar transport, cell wall synthesis, lignification, cell wall structure integrity, carbohydrate metabolism, RNA metabolism, respiration, indol acetic acid (IAA) metabolism, phenol metabolism, as part of the cell membranes, play significant role in pollination success and it plays a role in the trees to translocate $\mathrm{Ca}$ from the roots to other parts of the trees and deficiencies can contribute to poor fruit set. (Mengel et al., 2001; Mazher et al., 2006 and Roy et al., 2006). Boron may be applied to the soil or the foliage with good effect. Foliar fertilization has advantage of low application rates, uniform distribution of fertilizer materials, easiest method of application and quick responses to applied nutrients (Peryea 1994 and Khayyat et al., 2007). Several researches have shown that foliar application of Boron to foliage have a higher increase of fruit set, vegetative growth and Yield (Wojcik and Wojcik 2003 on Conference pear trees; Peryea et al., 2003 on apple trees, and Usenik and Stampar 2007 on Summit and Hedelfinger of sweet cherry).

The aim of the present research was to study the response of apple, Anna cultivar to nitrogen fertilization and foliar application with boron on fruit set and vegetative growth and fruit yield.

\section{MATERIALS AND METHOD}

The research was conducted on 10-year old Anna apple trees were grown on Malling Merton 106 rootstock during 2008 season. Planted at distances of 4x4m and trained in modified leader system in a private orchard of Anna apple trees growing at Al-Rashidia region, Mosul city, Iraq. The trees were selected as uniform as possible with $25 \pm 3 \mathrm{~cm}$ diameter trunks measured $30 \mathrm{~cm}$ above of the ground at the start of the study. In Table(1) the soil of the orchard was characterized by clay loam. The study involved four level of nitrogen fertilization $(0,60,120$ and $\left.180 \mathrm{~kg} . \mathrm{N} . \mathrm{h}^{-1}\right)$ and foliar application with four concentrations of boron fertilizer $(0$, 50,100 and $\left.150 \mathrm{mg} .1^{-1}\right)$ as Boric acid $(17 \% \mathrm{~B})$ was used, in a factorial experiment in Randomized Complete Block Design (RCBD) with 16 treatments (4NX4B levels) was arranged. Each treatment was replicated four times on two trees in the plot. Nitrogen was applied as urea $(46 \% \mathrm{~N})$ fertilizer was added as soil application in mid March at the begging of growth. Moreover, Boron was applied as Boric acid adding as foliar application. Boron sprayed twice, first at green-pink bud stage and the second after fruit setting one month later. Tween-20 as a wetting agent at $0.1 \%$ was added to all spraying solutions and spraying was done till runoff $\left(51\right.$. tree $\left.^{-1}\right)$. All selected trees received the regular agricultural and horticultural practices that usually followed in the orchard expected N and B fertilization. Surface irrigation system was followed in the orchard. At the harvest date twenty leaves from the middle part of the shoots were taken from each replicate for measuring leaf area according to Ahmed and Morsy (1999) using the following formula :

$\mathrm{La}=0.73(\mathrm{LxW})+0.16$

Where $\mathrm{La}=$ leaf area $\left(\mathrm{cm}^{2}\right), \mathrm{L}$ the maximum length of leaf and $\mathrm{W}$ the maximum width of leaf. At end of July as fruit reached maturity, trees were harvest then yield 
of each tree was recorded as $\mathrm{kg}$ and number of fruit. Fruit set was calculated from number of flowers to one month after fruit set were counted out on four comparable branches on four different parts of every tree using the following formula :

Fruit set $(\%)=\frac{\text { No. of fruit / branches }}{\text { Total No. of flowers/ branches }}$

Thirty fruit per tree were randomly taken for determination of following physical and chemical parameters such as average fruit weight $(\mathrm{g})$, the yield of the tree in the orchard directly. Total soluble solid (TSS)\% was determined by the use of a hand refractometer. Titratable acidity, values were measured by malic acid estimation in apple fruits according to Rangana (1986) and total chlorophyll in the leaves as Plummer (1974). The statistical analysis of data obtained was carried out by using a two-factorial analysis of variance, by Duncan's multiple range test at $5 \%$ level. SAS (2001) was use to analysis programs in computer.

Table (1): Soil properties of the experimental orchard from a depth of 30-70 cm.

\begin{tabular}{|c|c|c|c|}
\hline Soil property & Value & Soil property & Value \\
\hline $\mathrm{N}$ & $65 \mathrm{mg} \cdot \mathrm{Kg}^{-1}$ & $\mathrm{CaCo}_{3}(\%)$ & 237 \\
\hline $\mathrm{P}$ & $18 \mathrm{mg} \cdot \mathrm{Kg}^{-1}$ & $\mathrm{EC}\left(\mathrm{ds} \cdot \mathrm{m}^{-1}\right)$ & 0.88 \\
\hline $\mathrm{K}$ & $70 \mathrm{mg} \cdot \mathrm{Kg}^{-1}$ & Sand & 225 \\
\hline Organic mater & $6.2 \mathrm{gm} \cdot \mathrm{Kg}^{-1}$ & Clay & 350 \\
\hline $\mathrm{p}^{\mathrm{H}}$ & 7.81 & Loam & 425 \\
\hline \multicolumn{2}{|r|}{} & Texture & Clay loam \\
\hline
\end{tabular}

\section{RESULTS AND DISCUSSION}

Fruit set (\%) : Data in table (2) clearly show that single or combined application of $\mathrm{N}$ fertilization and foliar application of B was very effective in improving fruit set percentage compared with control. Fruit set percentage was increased with increasing $\mathrm{N}$ fertilization levels especially in $120 \mathrm{KgN}^{-1} \mathrm{~h}^{-1}(14.40 \%)$ compared with control treatment (10.34\%). In the same table the data showed that foliar application with Boric acid (B) caused significantly increased the fruit set percentage especially in $100 \mathrm{mgB} \cdot 1^{-1}(14.10 \%)$ compared with the less value $(11.47 \%)$ in control treatment. The combination application of $\mathrm{N}$ and $\mathrm{B}$ levels were significantly increased fruit set percentage of Anna apple trees especially in combination between $120 \mathrm{KgN}^{-1} \mathrm{~h}^{-1}+$ $100 \mathrm{mg} . .^{-1}$ which gave the highest percentage of fruit set (19.24\%) compared with the lowest value $(9.08 \%)$ in control treatment. It has been reported that $\mathrm{N}$ taken up from the soil application during the growing season can be quickly translocated to above ground and directly used for the production of new growth (Gu et al., 1987). Furthermore, nitrogen in a constituent of amino acid, which are required to synthesize proteins and other related compounds, it plays a role in almost all plant metabolic and increased fruit set processes (Marschner 1995 and Mengel et al., 2001). Fruit set increase could be due to enhance pollen germination, tube growth and increase the B concentration in the pollens by foliarly applied of boron (Mozafar,1989 ; Nyomora et al., 2000 and Peryea et al., 2003). Bould et al., (1984) reported that the boron requirement for generative growth (flower and seed production) is much higher than for vegetative growth. According to Lewis (1980) 
high boron levels in the stigma and style aer required for physiological inactivation of callose from the pollen tube walls by formation borate callose complexes.

Table (2): Effect of Nitrogen and Boron fertilization on fruit set \% of Anna apple trees.

\begin{tabular}{|c|c|c|c|c|c|}
\hline \multirow[b]{2}{*}{$\begin{array}{l}\text { Nitrogen levels } \\
\quad\left(\mathrm{Kg}^{-\mathrm{h}^{-1}}\right)\end{array}$} & \multicolumn{4}{|c|}{ Boron levels (mgB.1 $\left.{ }^{-1}\right)$} & \multirow[b]{2}{*}{$\begin{array}{l}\text { Means of } \\
\text { Nitrogen }\end{array}$} \\
\hline & 0 & 50 & 100 & 150 & \\
\hline 0 & $9.18 \mathrm{~g}$ & $10.18 \mathrm{fg}$ & $10.99 \mathrm{ef}$ & $11.01 \mathrm{ef}$ & $10.34 \mathrm{c}$ \\
\hline 60 & $9.08 \mathrm{~g}$ & $10.98 \mathrm{ef}$ & $14.80 \mathrm{c}$ & $16.80 \mathrm{~b}$ & $12.92 \mathrm{~b}$ \\
\hline 120 & $12.48 \mathrm{de}$ & $15.21 \mathrm{c}$ & $19.24 \mathrm{a}$ & $10.68 \mathrm{fg}$ & $14.40 \mathrm{a}$ \\
\hline 180 & $15.14 \mathrm{c}$ & $13.93 \mathrm{~cd}$ & $11.35 \mathrm{ef}$ & $9.84 \mathrm{fg}$ & $12.56 \mathrm{~b}$ \\
\hline Means of Boron & $11.47 \mathrm{c}$ & $12.57 \mathrm{~b}$ & $14.10 \mathrm{a}$ & $12.08 \mathrm{bc}$ & \\
\hline
\end{tabular}

* Means with the same letter are not significantly different at $5 \%$ probability level according to Duncans Multiple range test.

Finally, boron has both indirect and direct effect on fertilization. Indirect effects are probably related to the increase in amount and change in sugar composition of the nectar, whereby the flowers of species that rely on pollinating insects become more attractive to insects (Smith and Johnson, 1969 and Erikson, 1979). Direct effect boron are reflected by the close relationship between boron supply and pollenproducing capacity of the anthers, as well as the viability of the pollen grains (Argawala et al., 1981).

Leaf Area: Data in table (3) showed that different Nitrogen levels have significant effect on leaf area. The highest values $\left(40.43 \mathrm{~cm}^{3}\right)$ were obtained due to fertilizing with $120 \mathrm{KgN} \cdot \mathrm{h}^{-1}$ as compared with the lowest value $\left(30.11 \mathrm{~cm}^{2}\right)$ in $\mathrm{O} \mathrm{Kg} \mathrm{N} \cdot \mathrm{h}^{-1}$. Leaf area was noticeably increased due to foliar application of boron. The highest values $\left(37.49 \mathrm{~cm}^{-2}\right)$ were obtained due to application with $100 \mathrm{mgB} \cdot 1^{-1}$ compared with the lowest value $\left(33.41 \mathrm{~cm}^{-2}\right)$ in $0 \mathrm{mg} \mathrm{B.} 1^{-1}$ treatment. The best results were obtained from the interaction between the levels of $\mathrm{N}$ and $\mathrm{B}$ fertilization followed by application of $120 \mathrm{KgN} \cdot \mathrm{h}^{-1}+100 \mathrm{mg} \mathrm{B} \cdot \mathrm{L}^{-1}\left(43.83 \mathrm{~cm}^{2}\right)$ compared with the lowest value of leaf area $\left(28.31 \mathrm{~cm}^{2}\right)$ in the control treatment. Leaf area increment could be due to improving cell size and cell number by nitrogen application and increase in net photosynthesis and growth of leaves (Marschner, 1995). While the leaf area increase by foliar application of boron could be due to boron is required primarily for cell elongation rather than for cell division (Birnbaum et al., 1974 and Lovatt et al., 1981) by effect on Cytokinin (Marschner, 1995). On other hand, the effect of the studied $\mathrm{N}$ and $\mathrm{B}$ on activating of both cell division and elongating in the meristematic tissues as well as the biosynthesis of organic foods (Nijjar, 1985) could explain their positive action on increasing leaf area (Ahmed and Morsy, 2001).

Chlorophyll content (mg.g fresh weight): Data listed in Table (4) revealed that significant differences were detected between each nitrogen and Boron levels on chlorophyll content of Anna apple leaves. The best results were obtained due to 120 $\mathrm{Kg} \mathrm{N} . \mathrm{h}^{-1}$ fertilization (10.48 mg. $\mathrm{g}^{-1} \mathrm{~F} . \mathrm{W}$.) as compared with the lowest value obtained in $0 \mathrm{Kg} \mathrm{N} \cdot \mathrm{h}^{-1}$ (8.44 mg.g ${ }^{-1} \mathrm{~F} . \mathrm{W}$.). Chlorophyll content in the leaves was gradually increased due to the foliar application of Boron. The highest values were 
obtained due to the application of $150 \mathrm{mg} \mathrm{B} \cdot \mathrm{l}^{-1}$ (9.98 mg. $\mathrm{g}^{-1} \mathrm{~F} . \mathrm{W}$.), while the lowest value $\left(8.57 \mathrm{mg} . \mathrm{g}^{-1} \mathrm{~F} . \mathrm{W}\right.$.) obtained in $0 \mathrm{mg} \mathrm{B} . \mathrm{l}^{-1}$ treatment. Data of interaction between $\mathrm{N}$ and $\mathrm{B}$ levels gave the best value $\left(11.91 \mathrm{mg} . \mathrm{g}^{-1} \mathrm{~F} . \mathrm{W}\right.$.) of chlorophyll content specially by application $120 \mathrm{Kg} \mathrm{N} \cdot \mathrm{h}^{-1}+100 \mathrm{mg} \mathrm{B} \cdot \mathrm{L}^{-1}$ while the lowest content of chlorophyll (7.85 mg.g ${ }^{-1} \mathrm{~F} . \mathrm{W}$.) in the leaves in control treatment. Chlorophyll concentration in leaves increment could be due to nitrogen is an integral part of chlorophyll manufacture through photosynthesis (Marschner, 1995). On other hand, Nitrogen in a constituent of amino acid, which are required to the synthesize of proteins and other related compounds. However, nitrogen fertilization caused increase in net photosynthesis and growth of leaves (Marschner, 1995). Chlorophyll content increase could be due enhance growth of plant and its roles for many metabolism processes.

Table (3): Effect of Nitrogen and Boron fertilization on leaf area of Anna apple trees.

\begin{tabular}{|c|c|c|c|c|c|}
\hline \multirow{2}{*}{$\begin{array}{l}\text { Nitrogen levels } \\
\left(\text { Kg. }^{-1}\right)\end{array}$} & \multicolumn{4}{|c|}{ Boron levels (mgB. $\left.{ }^{-1}\right)$} & \multirow[b]{2}{*}{$\begin{array}{l}\text { Means of } \\
\text { Nitrogen }\end{array}$} \\
\hline & 0 & 50 & 100 & 150 & \\
\hline 0 & $28.31 \mathrm{f}$ & $29.85 \mathrm{f}$ & $31.01 \mathrm{ef}$ & $31.28 \mathrm{ef}$ & $30.11 \mathrm{~d}$ \\
\hline 60 & $31.45 \mathrm{ef}$ & $33.91 \mathrm{de}$ & $36.11 \mathrm{~cd}$ & $35.91 \mathrm{~cd}$ & $34.34 \mathrm{c}$ \\
\hline 120 & $36.87 \mathrm{~cd}$ & $38.18 \mathrm{c}$ & $43.83 \mathrm{a}$ & $42.11 \mathrm{ab}$ & $40.43 \mathrm{a}$ \\
\hline 180 & $37.01 \mathrm{~cd}$ & $38.18 \mathrm{c}$ & $39.92 b c$ & $39.01 \mathrm{bc}$ & $38.38 \mathrm{~b}$ \\
\hline Means of Boron & $33.41 \mathrm{c}$ & $35.21 \mathrm{~b}$ & $37.49 \mathrm{a}$ & $37.15 \mathrm{a}$ & \\
\hline
\end{tabular}

Table (4): Effect of Nitrogen and Boron fertilization on total chlorophyll content (mg. ${ }^{-1}$ f.w) of Anna apple leaves.

\begin{tabular}{|c|c|c|c|c|c|}
\hline \multirow{2}{*}{$\begin{array}{c}\text { Nitrogen levels } \\
\left(\text { Kg. } \mathrm{h}^{-1}\right)\end{array}$} & 0 & 50 & 100 & 150 & $\begin{array}{c}\text { Means of } \\
\text { Nitrogen }\end{array}$ \\
\cline { 2 - 6 } & $7.85 \mathrm{f}$ & $8.03 \mathrm{ef}$ & $8.87 \mathrm{def}$ & $9.01 \mathrm{~b}-\mathrm{e}$ & $8.44 \mathrm{~d}$ \\
\hline 0 & $8.32 \mathrm{ef}$ & $8.81 \mathrm{def}$ & $8.89 \mathrm{def}$ & $9.80 \mathrm{bcd}$ & $8.96 \mathrm{c}$ \\
\hline 60 & $8.97 \mathrm{cde}$ & $9.98 \mathrm{bc}$ & $11.91 \mathrm{a}$ & $11.04 \mathrm{a}$ & $10.48 \mathrm{a}$ \\
\hline 120 & $9.12 \mathrm{~b}-\mathrm{e}$ & $9.67 \mathrm{bcd}$ & $10.01 \mathrm{bc}$ & $10.07 \mathrm{~b}$ & $9.72 \mathrm{~b}$ \\
\hline 180 & $8.57 \mathrm{c}$ & $9.12 \mathrm{~b}$ & $9.92 \mathrm{a}$ & $9.98 \mathrm{a}$ & \\
\hline Means of Boron & &
\end{tabular}

* Means with the same letter are not significantly different at 5\% probability level according to Duncans Multiple range test.

Total Solubl Solid (TSS): Data in table (5) showed that increasing Nitrogen fertilization levels increased TSS content, meanwhile, the best result were obtained from adding $120 \mathrm{Kg} \mathrm{N} \cdot \mathrm{h}^{-1}(15.10 \%)$, while adding high levels fertilizer caused decrease the TSS. Application of boron either single or in combination with nitrogen significantly improved fruit quality in term of increasing total soluble solids comparing with the control. The highest values of TSS (14.88\%) were obtained due to application of $150 \mathrm{mg} \mathrm{B} .1^{-1}$ compared with the lowest value $(14.09 \%)$ in $0 \mathrm{mgB} . \mathrm{l}^{-1}$ treatment. However, the best results were obtained from the interaction between $\mathrm{N}$ and B levels followed by application of $120 \mathrm{Kg} \mathrm{N} \cdot \mathrm{h}^{-1}+100$ 
mg B. $1^{-1}(15.38 \%)$ compared with the lowest value $(13.61 \%)$ of the TSS in the control treatment.

Table (5): Effect of Nitrogen and Boron fertilization on TSS of Anna apple fruit.

\begin{tabular}{|c|c|c|c|c|c|}
\hline \multirow{2}{*}{$\begin{array}{c}\text { Nitrogen levels } \\
\left(\mathrm{Kg}^{\left.-\mathrm{h}^{-1}\right)}\right.\end{array}$} & \multicolumn{4}{|c|}{ Boron levels (mgB. $1^{-1}$ ) } & \\
\hline & 0 & 50 & 100 & 150 & $\begin{array}{l}\text { Means of } \\
\text { Nitrogen }\end{array}$ \\
\hline 0 & $13.61 \mathrm{~d}$ & $14.01 \mathrm{~cd}$ & $14.39 \mathrm{a}-\mathrm{d}$ & $14.88 \mathrm{abc}$ & $14.22 \mathrm{~b}$ \\
\hline 60 & $14.01 \mathrm{~cd}$ & $14.91 \mathrm{abc}$ & $15.03 \mathrm{abc}$ & $15.12 \mathrm{abc}$ & $14.77 \mathrm{a}$ \\
\hline 120 & $14.53 \mathrm{a}-\mathrm{d}$ & $15.20 \mathrm{abc}$ & $15.38 \mathrm{a}$ & $15.30 \mathrm{ab}$ & $15.10 \mathrm{a}$ \\
\hline 180 & $14.21 \mathrm{a}-\mathrm{d}$ & $14.32 \mathrm{a}-\mathrm{d}$ & $14.11 \mathrm{bcd}$ & $14.21 \mathrm{a}-\mathrm{d}$ & $14.21 \mathrm{~b}$ \\
\hline Means of Boron & $14.09 \mathrm{~b}$ & $14.61 \mathrm{a}$ & $14.73 \mathrm{a}$ & $14.88 \mathrm{a}$ & \\
\hline
\end{tabular}

Total Acidity (TA) \% : Results in table (6) declared that nitrogen fertilization had a significant decrease in total acidity especially in $120 \mathrm{KgN}^{-1}(0.31 \%)$ treatment. In the same table the data showed that foliar application with boron caused significantly decreased in total acidity with increasing B application especially in 100 and $150 \mathrm{mg} \mathrm{B.} 1^{-1}(0.36 \%)$. Concerning the interactions between $\mathrm{N}$ and $\mathrm{B}$ application results in table (5) indicated that TA were significantly decrease especially in $120 \mathrm{KgN} . \mathrm{h}^{-1}+100 \mathrm{mg} \mathrm{B} \cdot \mathrm{l}^{-1}$ treatment $(0.26 \%)$ compared with control treatment $(0.51 \%)$.

Total soluble solid (TSS) increase and decrease of total acidity (TA) could be due to nitrogen fertilization caused increase in net photosynthesis and carbohydrate production in the leaves and transport to fruit. TSS increase and decrease of TA could be to the role of boron in carbohydrate metabolism is focused on the synthesis of cell wall material and the transport of sugars (Marschner, 1995). Boron plays a key role in higher plants by facilitating the short and long distance transport of sugars via the formation of borate - sugar complexes and formation of cis-dol borate complexes and boron may facilitate sugar uptake by leaves (Marschner 1995 and Mengel et al., 2001). The influence of the studied chemicals on stimulating carbohydrate biosynthesis as a result of their effect in improving the vegetative growth of the tree could induce better fruit quality (Ahmed and Morsy, 2001). However, the use of microelement could reduce the leaf starch content, owing to a more intensive transformation of starch into sugar, and its translocation to the fruits (Rus'ko, 1968).

Table (6): Effect of Nitrogen and Boron fertilization on Total Acidity of Anna apple fruit.

\begin{tabular}{|c|c|c|c|c|c|}
\hline \multirow{2}{*}{$\begin{array}{c}\text { Nitrogen levels } \\
(\text { Kg.h }\end{array}$} & \multicolumn{4}{|c|}{ Boron levels $\left(\mathrm{mgB} . \mathrm{l}^{-1}\right)$} & \\
\cline { 2 - 6 } & 0 & 50 & 100 & 150 & $\begin{array}{c}\text { Means of } \\
\text { Nitrogen }\end{array}$ \\
\hline 0 & $0.51 \mathrm{a}$ & $0.47 \mathrm{~b}$ & $0.42 \mathrm{c}$ & $0.40 \mathrm{~cd}$ & $0.45 \mathrm{a}$ \\
\hline 60 & $0.42 \mathrm{c}$ & $0.46 \mathrm{~b}$ & $0.40 \mathrm{~cd}$ & $0.39 \mathrm{cde}$ & $0.42 \mathrm{~b}$ \\
\hline 120 & $0.36 \mathrm{ef}$ & $0.30 \mathrm{~g}$ & $0.26 \mathrm{~h}$ & $0.30 \mathrm{~g}$ & $0.31 \mathrm{~d}$ \\
\hline 180 & $0.39 \mathrm{cde}$ & $0.37 \mathrm{def}$ & $0.36 \mathrm{ef}$ & $0.35 \mathrm{f}$ & $0.37 \mathrm{c}$ \\
\hline Means of Boron & $0.42 \mathrm{a}$ & $0.40 \mathrm{~b}$ & $0.36 \mathrm{c}$ & $0.36 \mathrm{c}$ & \\
\hline
\end{tabular}

* Means with the same letter are not significantly different at 5\% probability level according to Duncans Multiple range test. 
Fruit weight (g) : It is evident from the data in table (7) that fruit weight were positively affected by the application of nitrogen and boron either singly or in combination compared with control treatment. The maximum value $(149.79 \mathrm{~g})$ were obtained in trees received $120 \mathrm{KgN} \cdot \mathrm{h}^{-1}$ compared with minimum value $(131.99 \mathrm{~g})$ in the trees were received $0 \mathrm{KgN} . \mathrm{h}^{-1}$. While the trees were received $100 \mathrm{mgB} \cdot \mathrm{l}^{-1}$ gave the highest value (146.21g) of fruit weight. The combination application of $\mathrm{N}$ and $\mathrm{B}$ were significantly increased the fruit weight of Anna apple trees especially in combination between $120 \mathrm{KgN} \cdot \mathrm{h}^{-1}+100 \mathrm{mg} \mathrm{B} \cdot \mathrm{l}^{-1}$ which gave the highest value (166.81g) of fruit weight compared with the lowest value $(123.10 \mathrm{~g})$ in control treatment. Fruit weight increase could be due to improving cell size and fruit size and the key role of $\mathrm{N}$ on stimulating the biosynthesis of organic foods and cell division (Nijjar, 1985) could explain the present results. The important role of B in enhancing cell division, cell enlargement building and transporting the organic foods could explain their effects in improving fruit weight (Wojcik, et al. 1999 and Abdel- Aziz et al., 2001).

Table (7): Effect of Nitrogen and Boron fertilization on fruit weight of Anna apple trees.

\begin{tabular}{|c|c|c|c|c|c|}
\hline \multirow{2}{*}{$\begin{array}{c}\text { Nitrogen levels } \\
\left(\text { Kg. }^{-1}\right)\end{array}$} & 0 & 50 & 100 & 150 & $\begin{array}{c}\text { Means of } \\
\text { Nitrogen }\end{array}$ \\
\cline { 2 - 6 } & $123.10 \mathrm{~g}$ & $130.31 \mathrm{f}$ & $136.81 \mathrm{de}$ & $137.77 \mathrm{cde}$ & $131.99 \mathrm{~d}$ \\
\hline 0 & $130.81 \mathrm{f}$ & $135.91 \mathrm{e}$ & $139.11 \mathrm{cde}$ & $139.78 \mathrm{cde}$ & $136.40 \mathrm{c}$ \\
\hline 60 & $137.7 \mathrm{cde}$ & $140.92 \mathrm{cde}$ & $166.81 \mathrm{a}$ & $153.74 \mathrm{~b}$ & $149.79 \mathrm{a}$ \\
\hline 120 & $138.17 \mathrm{cde}$ & $141.81 \mathrm{~cd}$ & $142.11 \mathrm{c}$ & $140.91 \mathrm{cde}$ & $140.75 \mathrm{~b}$ \\
\hline 180 & $132.45 \mathrm{~d}$ & $137.24 \mathrm{c}$ & $146.21 \mathrm{a}$ & $143.05 \mathrm{~b}$ & \\
\hline Means of Boron &
\end{tabular}

* Means with the same letter are not significantly different at $5 \%$ probability level according to Duncans Multiple range test.

Tree yield (Kg.tree ${ }^{-1}$ ) : It can be stated from the data in table (8) that the yield was positively affected with the application of Nitrogen and Boron either applied singly or in combinations compared with the control treatment. Application of nitrogen fertilization was favorable in improving the yield of fruits per tree especially in adding $120 \mathrm{Kg} \mathrm{N} . \mathrm{h}^{-1}$ which gave $43.76 \mathrm{Kg} \cdot$ tree $^{-1}$.

Table (8): Effect of Nitrogen and Boron fertilization on tree yield of Anna apple trees.

\begin{tabular}{|c|c|c|c|c|c|}
\hline \multirow{2}{*}{$\begin{array}{l}\text { Nitrogen levels } \\
\left(\mathrm{Kg}^{\left.-\mathrm{h}^{-1}\right)}\right.\end{array}$} & \multicolumn{4}{|c|}{ Boron levels (mgB. $\left.1^{-1}\right)$} & \\
\hline & 0 & 50 & 100 & 150 & $\begin{array}{l}\text { Means of } \\
\text { Nitrogen }\end{array}$ \\
\hline 0 & $23.81 \mathrm{f}$ & $25.14 \mathrm{f}$ & $28.41 \mathrm{e}$ & $29.11 \mathrm{e}$ & $26.62 \mathrm{~d}$ \\
\hline 60 & $30.18 \mathrm{e}$ & $33.01 \mathrm{~d}$ & $34.19 \mathrm{~d}$ & $35.01 \mathrm{~d}$ & $33.10 \mathrm{c}$ \\
\hline 120 & $38.72 \mathrm{c}$ & $40.13 \mathrm{bc}$ & $48.11 \mathrm{a}$ & $48.09 \mathrm{a}$ & $43.76 \mathrm{a}$ \\
\hline 180 & $39.77 \mathrm{bc}$ & $40.11 \mathrm{bc}$ & $40.91 \mathrm{bc}$ & $41.08 \mathrm{~b}$ & $40.47 \mathrm{~b}$ \\
\hline Means of Boron & $33.12 \mathrm{c}$ & $34.60 \mathrm{~b}$ & $37.91 \mathrm{a}$ & $38.32 \mathrm{a}$ & \\
\hline
\end{tabular}


On other hand foliar application of $150 \mathrm{mg} \mathrm{B.1^{-1 }}$ gave $38.32 \mathrm{Kg} \cdot \mathrm{tree}^{-1}$ compared with $33.12 \mathrm{Kg}$.tree ${ }^{-1}$ in $0 \mathrm{Kg} \mathrm{B.}{ }^{-1}$ treatment (table 8). Application of nitrogen with boron measurably raised the yield. The maximum yield was recorded from the trees received $120 \mathrm{Kg} \mathrm{N} \cdot \mathrm{h}^{-1}\left(48.11 \mathrm{Kg} \cdot \mathrm{tree}^{-1}\right)$ while the control treatment gave the minimum yield $\left(23.81 \mathrm{Kg}\right.$.tree $\left.{ }^{-1}\right)$. The promotion occurred on Yield per tree in response to $\mathrm{N}$ fertilization is an important goal in all agricultural system and increasing the period for fruits to use assimilates (Dong et al., 2005). Nitrogen promotes rapid growth, increase leaf size and fruit quality, hastens crop maturity and promotes fruit and seed development (Marschner, 1995) . Furthermore, adequate nitrogen is essential for tree growth, leaf cover, blossom formation, fruit set and fruit size, all of which combine to determine crop yield (Bright, 2005). The yield per tree increase could be due to the effect of boron on reducing fruit splitting and the increasing fruit set and fruit weight as noticed in Tables ( 2 and 7$)$ could explain their effect in improving tree yields.

Finally, under the conditions of this experiment, it is advisable to use nitrogen fertilization with $120 \mathrm{Kg} \mathrm{N} . \mathrm{h}^{-1}$ and twice foliar application with $100 \mathrm{mg} \mathrm{B}^{-1}$ to gave good quantity and quality of the yield of Anna apple trees.

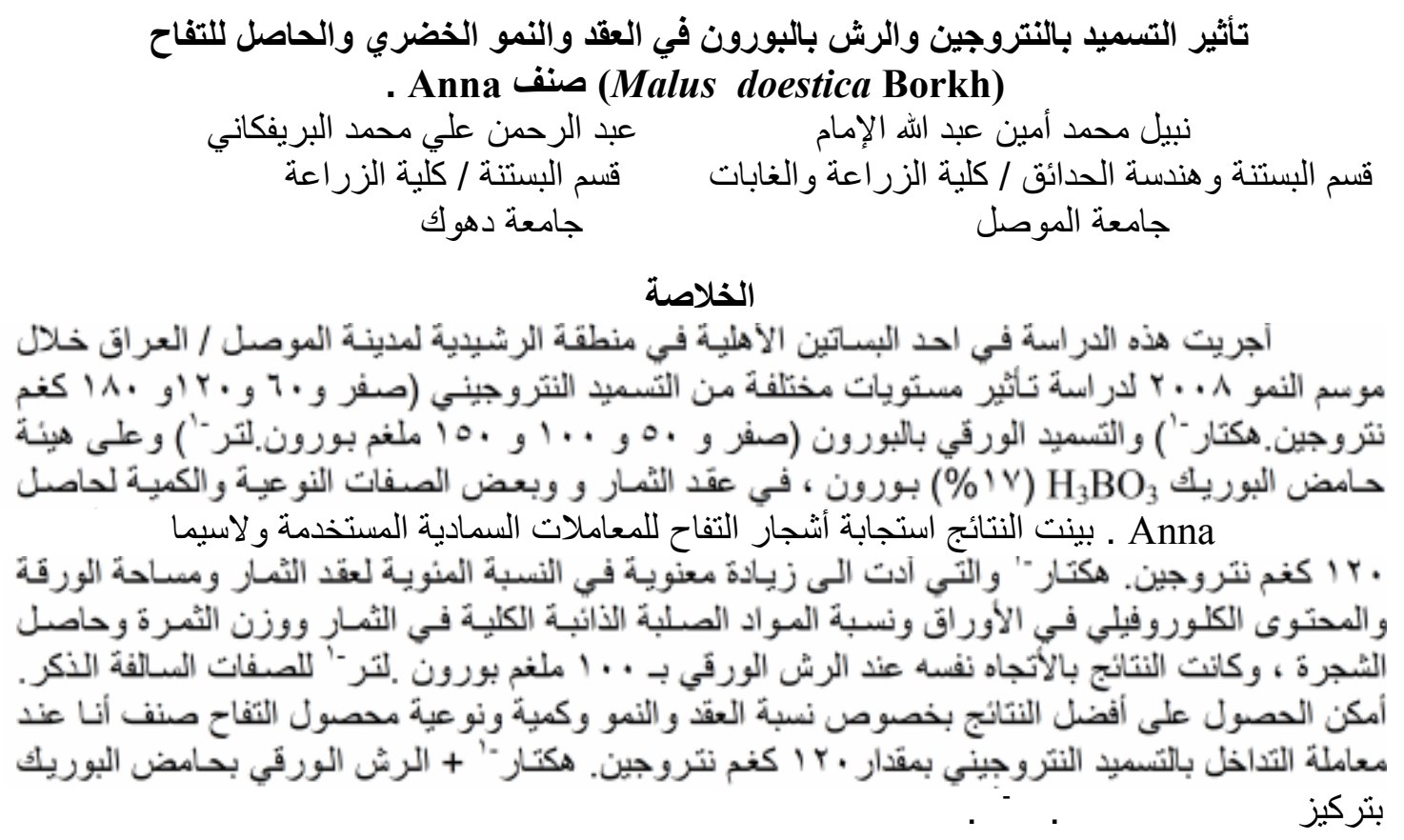

\section{REFERENCES}

Abdel- Aziz, G.A.; F.F. Ahmed and M.S. El-Shamaa (2001). Effect of varing N, K, and $\mathrm{Mg}$ applications on growth, leaf chemical composition and productivity of Banaty grapevines. The fifth Arabian Horticulture conferences, Ismailai, Egypt, March 24-28.P.83-90.

Ahmed, F.F. and M.H. Morsy (1999). A new method for measuring leaf area in different fruit species. Minia J. Agric. Res. \& Develop.19: 97- 105.

Ahmed, F.F. and M.H. Morsy (2001). Response of "Anna" Apples trees grown in the new reclamed land to application of some nutrient and ascorbic acid. The Fifth Arabian horticulture Conference, Ismailia, Egypt, March, 24-48, P.27-34. 
Argawala, S.C ; P.N. Sharma; C. Chaterjee and C.P. Sharma (1981). Development and enzymatic changes during pollen development in boron deficient maize plants . J. plant Nutr. 3: 329- 336.

BI, G.; C.F. Scagel; L. Cheng; S. Dong and H. Fuchigami (2003). Spring growth of Almond nursery trees depends upon nitrogen from both plant reserves and spring fertilizer application. J. Hort. Sci. \& Biotech. 78(6): 853 - 858.

Birnabaum, E.H.; C.A. Beasley and W.M. Dugger (1974). Boron deficiency in unfertilized cotton (Gossypium hirsutum) ovules grown in vitro. Plant Physiol. 54: $931-935$.

Bould, C., Hewitt, F.J. and P.Needham. (1984). Diagnosis of Mineral Disorder in plant. Vol.1, principles. CIP Chemical, New York, pp. 68-69.

Bright, J. (2005). Apple and Pear nutrition. NSW Department of Primary Industries. Primefact 85. pp. 1-12.

Dong, S.; L. Cheng; C.F. Seagel and L.H. Fuchigami (2005). Timing of urea application affects leaf and root $\mathrm{N}$ uptake in young Fuji/M9 apple trees. J. Hortic . Sci. and Biotech. 80: 116-120.

Eriksson, M. (1979). The effect of boron on nectar production and seed setting of red clover (Trifolium pretense L.), Swed. J. Agric. Res., 9: 37.

Ernani, P.R. and J. Dias (1999). Soil nitrogen application in the spring did not increase apple yield . Ciencia Rural, 59(4): 645- 649.

Gu, M.; H. Shu and H. Zhou (1987) Studies of nitrogen nutrition in apple trees. V. characteristics of update and translocation of $\mathrm{N}^{15}$ in different forms. $\mathrm{J}$. Shandong Agric. Univ., 17: 45-52.

Khayyat, M.; E. Tafazoli; S. Eshghi and S. Rajaee (2007). Effect of nitrogen, boron, potassium and zinc sprays on yield and fruit quality of date palm. Am-Euras. J. Agric. and Environ. Sci., 2(3) : 289- 296.

Klein, I.; I. Levin; B. Bar-Yosef; R. Assaf and A. Berkovitz (2006) Drip nitrogen fertigation of Starking Delicious apple trees. Plant and Soil 119(2) : 305- 314.

Krisanapook, K.; S. Subhadrabandhu and R. Ogata (1995). Induction of budbreak in apple trees that recived insufficient chilling by hydrogen cyanamide. Kasetsart J. (Nat. Sci) 29: 239- 245.

Lewis, D.H. (1980). Are their inter-relations between the metabolic role of boron. Synthesis of phenolic phytoalexins and the germination of pollen. J. New Phytol., 84: 261- 270.

Lovatt, C.J.; L.S. Albert and G.C. Tremblay (1981). Synthesis, salvage and catabolism of uridine nucleotides in boron- deficient squash root. Plant Physiol, 68: 1389- 1394.

Marschner, H. (1995) Mineral Nutrition of Higher Plant. Academic Press. Orlando F.L.

Mazher, A.A.M.; Zaghloul, S.M. and Yassen, A.A. (2006). Impact of boron fertilizer on growth and chemical constituents of Taxodium distichum grown under water regime. World J. Agric. Sci. 2 (4) : 412- 420.

Mengel, K.; E.A. Kirk by ; H. Kosegarten and T. Appel (2001). Princoples plant Nutrition . Kluwer Academic publisher Dordrecht.

Mozafar, A. (1989). Boron effect on mineral nutrients of maize. Agro. J. 81, 285.

Nijjar, G.S. (1985). Nutrition of Fruit Trees. Kalyani Publishers, New Delhi, India. 
Nyomora, A.M.S.; P.H. Brown; K. Pinney and V.S. polito (2000). Foliar application of boron to Almond trees affecteds pollen quality.J. of Ameri. Soci. for Hort. Sci. 125:265.

Peryea, F. J. (1994) Boron nutrition in deciduous tree fruit. P. 95- 99. In : A.B. Peterson and R.G. Stevens (eds) Tree fruit nutrition. Good Fruit GrowerYakima, Wash.

Peryea, F.J. ; D. Nielsen and G. Neilsen (2003). Boron maintenance sprays for apple : Early season applications and tank- mixing with calcium chloride. Hort Science 38: 542- 546.

Plummer, D.T. (1974). An introduction to Practical Biochemistry. McGraw-Hill Book Company (UK) Limited England.

Ranganna, S. (1986) Hand book of analysis and quality control for fruit and vegetable products. Tota McGrawHill Publishing Company Limited New Delhi.

Roy,R.N;A.Finck;G.J.Blair and H.L.S.Tandon(2006).Plant nutrition for food security. Aguide for integrated nutrient management. Food and Agriculture Organizationof the United Nations, Rom.

Rus'ko, O.O. (1968). The effect of micro elements on the carbohydrate metabolism in vines. Vines Kyivs'k Univ. Ser. Ser. Bio. 10: 108-112.

SAS (2001) Statistical Analysis System Institute Inc. Cary NC. 27511, USA.

Smith, R.H. and W. C. Johnson (1969). Effect of boron on white clover nectar production. Crop Sci. Vol. 9: 75.

Swierczynski, Sl.; Al. Stachowiak and G. Gradinariu (2007). Apple tree growth and mineral elements content from the leaves of grafted apple trees, cultivated in a nursery, and the influence of chemical treatments. Cercetari Agronomice in Moldova. Anul. 3 (131): 33-38.

Usenik, V. and F. Stamper (2007). Effect of late season boron spray on boron accumulation and fruit set of Sumit and Hedelfinger sweet cherry (Prunus avium L.). Acta Agricultura Slovenca. 89 (1) : 51-58.

Wojcik, P; G. Cieslinski and M. Mika (1999). Apple yield and fruit quality as influenced by boron applications. J. Plant Nutrition . 22(9) : 1365- 1377.

Wojcik, P. and M. Wojcik (2003). Effect of boron fertilization on Conference pear tree vigor, nutrition and fruit yield and storability. Plant and Soil . $256: 413$. 